\title{
Memorization of heavy metals by scales of the seagrass Posidonia oceanica, collected in the NW Mediterranean
}

\author{
M. Roméo ${ }^{1}$, M. Gnassia-Barelli ${ }^{1}$, T. Juhel ${ }^{1}$, A. Meinesz ${ }^{2}$ \\ ${ }^{1}$ I.N.S.E.R.M. U.303 ‘Mer et Santé', Laboratoire de Toxicologie Marine, Faculté de Médecine, UNSA, F-06107 Nice Cedex 2, France \\ ${ }^{2}$ CNRS EP 75, Laboratoire Environnement Marin Littoral, Faculté des Sciences, UNSA, Parc Valrose, F-06034 Nice Cedex, France
}

\begin{abstract}
Concentrations of $\mathrm{Cd}, \mathrm{Cu}, \mathrm{Fe}, \mathrm{Pb}$ and $\mathrm{Zn}$ were measured in scales of the seagrass Posidonia oceanica from different areas of the French NW Mediterranean: the Cote d'Azur and Corsica. Scales are basal parts of the seagrass which remain fixed on the rhizomes when leaves of $P$. oceanica die. Scales do not decay and the cyclic variation of their thickness permits retroactive dating (iepudochronology). Heavy metal concentrations were determined in the scales of $P$. oceanica dated by lepidochronology. Scales from $P$. oceanica collected from the Côte d'Azur (analysis of lepidochronological years from 1982 to 1992) generally showed concentrations of $\mathrm{Cu}, \mathrm{Fe}, \mathrm{Pb}$ and $\mathrm{Zn}$ to be greater than those measured in samples from Corsica (analysis of lepidochronological years from 1972 to 1992). In contrast, Cd concentrations recorded in scales from Corsica were higher than in those from Côte d.Azur. The reasons for these high $\mathrm{Cd}$ values are unknown. There was a general tendency for metal concentrations in P. oceanica scales collected on the Côte d'Azur to decrease with time. In Villefranchesur-Mer, where there are many pleasure boats, large concentrations of Cu were found in $P$. oceanica scales. These concentrations had increased in recent years.
\end{abstract}

KEY WORDS: Trace metals · Posidonia oceanica $\cdot$ Lepidochronology Mediterranean

\section{INTRODUCTION}

Seagrass Posidonia oceanica (L.) Delile is a good biomonitor of heavy metals because leaves and rhizomes are able to accumulate metals such as mercury (Augier et al. 1977, Maserti et al. 1988), copper, lead and cadmium (Chabert et al. 1983, Malea \& Haritonidis 1989, Gnassıa-Barelli et al. 1991)

Posidonia oceanica is perennial; when leaves die, only the blade becomes detached, the sheathing base remains fixed on the nonputrefying rhizome and is then called a 'scale'. Scale thickness shows cyclic variations according to insertion rank along the rhizome. Over a 1 yr period, observation of newly formed scales at the rhizome apex also showed cyclic variations in thickness (Pergent et al. 1983, Pergent 1987). This phenomenon allows dating of the scales in the rhizome and has been called 'lepidochronology' (from Greek lepidos, meaning scales; Boudouresque et al. 1983, Pergent et al. 1983, 1989).
Calmet et al. (1988) reported that at a Mediterranean site the distribution of ${ }^{137} \mathrm{Cs}$ with time, from 1950 to 1984, in scales of Posidonia oceanica displayed a signal corresponding to ${ }^{137} \mathrm{Cs}$ activity in the sea, as estimated from terrestrial fallout activity, residence time in the pelagic environment and the half-life of ${ }^{137} \mathrm{Cs}$. The authors called this phenomenon 'memorization' and hypothesized that scales can record radionuclide contamination, particularly of long-lived radionuclides, over long periods. Pergent-Martini (1992) showed that the variations of copper, zinc and lead concentrations in $P$. oceanica scales as a function of lepidochronological years were correlated; these variations might be related to those observed in the environment as a function of time.

As a consequence of the results given by the abovementioned authors, Posidonia oceanica, dissected by lepidochronological procedures, may offer a timeseries of certain environmental parameters, and pollutant concentrations in scales may reflect previous 
levels of pollutants in the environment. In this study, concentrations of cadmium, copper, iron, lead and zinc were measured in dated scales of $P$. oceanica. Seagrass was collected at the entrance of some pleasure-boat harbours from the Côte d'Azur to evaluate the longterm impact of dilution of antifouling paints on the heavy metal content of $P$. oceanica. A comparison of results was made with samples collected in the southeast of Corsica ('protected area'), which is considered as a very clean area, far from any harbour.

\section{MATERIALS AND METHODS}

Study area. Posidonia oceanica was collected by scuba diving in the infralittoral zone between 0 and $20 \mathrm{~m}$. The choice of sampling stations on the Cote d'Azur took into consideration the abundance of seagrasses and the well-known impact of coastal development on the infralittoral zone along the coastline (Meinesz et al. 1990). Fig. 1 shows the study area (Cote d'Azur and Corsica) and details the sampling stations.

The station 'Cap Martin' is situated in an area of shallow bottoms occupied by waterfront developments built on the sea (e.g. new and old pleasure boat harbours, artificial beaches) representing an occupation rate of $19.7 \%$ (Meinesz et al. 1990). Two samplings were performed there on 23 October 1992 and 20 April 1993. The 2 stations at Villefranche-sur-Mer are located in a less-developed zone (occupation rate $9.10 \%$; Meinesz et al. 1990); Rochambeau station is used as a mooring by pleasure boats in summer, whereas La Darse station is situated in the channel leading into the pleasure-boat harbour and shipyard of Villefranchesur-Mer. Collection of Posidonia oceanica was performed on 19 May 1992 and 4 June 1992 from Rochambeau and La Darse, respectively. A sampling was also performed in Corsica in the protected area of Lavezzi (Natural Park) facing the Gavetti Islands, near Bonifacio (Fig. 1).

Lepidochronological analysis. Orthotropic rhizomes of Posidonia oceanica without ramifications were chosen for a good lepidochronological analysis. This analy- sis was performed according to Pergent (1987). For each rhizome, the sheaths (scales) were carefully detached and numbered according to their insertion rank from the older (near the base) to the more recent (near the living leaves). Scales belonging to the same lepidochronological year were then grouped together. A lepidochronological year corresponds to a period of approximately 1 yr during which scale thickness ranges from one minimum value to another one.

Chemical analyses. Samples were carefully rinsed with ammonium formate $\left(88 \mathrm{~g} \mathrm{l}^{-1}\right)$ and dried to constant weight $\left(60^{\circ} \mathrm{C}\right)$. Digestion of samples was carried out according to Roméo et al. (1992). Metal concentrations were determined by atomic absorption spectrophotometry (GBC 904 AA) with flame for $\mathrm{Cu}, \mathrm{Fe}$ and $\mathrm{Zn}$ and with a graphite furnace (GBC 3000 with PAL 3000 autosampler) for $\mathrm{Cd}$ and $\mathrm{Pb}$. Deuterium background was used when necessary. The analytical procedure was checked using standard reference material (sea lettuce Ulva lactuca, CRM 279) provided by the Community Bureau of Reference (Commission of the European Community).

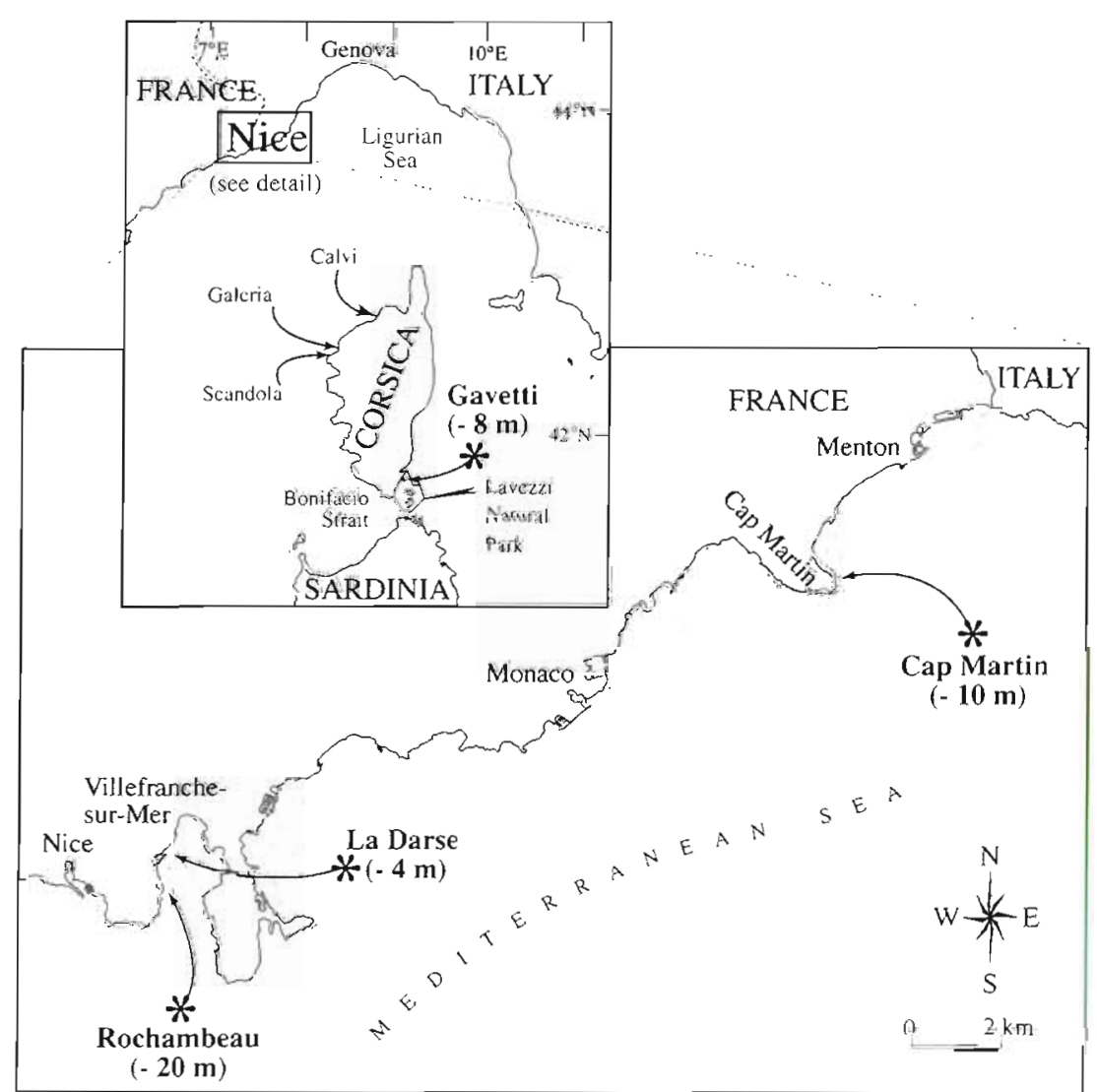

Fig. 1 Location of sampling stations (*). Rochambeau (mean number of lepidochronological years (MNLY) 10, sampling date (SD) 19 May 1992], La Darse (MNLY 10. SD 4 June 1992), Cap Martin (MNLY 7, SD 23 October 1992 and 20 April 1993). Gavetti, Corsica (MNLY 20, SD 25 September 1992) 


\section{RESULTS}

Mean metal concentrations ( \pm 1 standard deviation) in the scales of Posidonia oceanica are shown in Tables 1 to 4 for the stations Corsica, Rochambeau, La Darse and Cap Martin, respectively. For this last station, data from 2 sampling dates were grouped together as there were not significant differences in metal concentrations between dates. In the tables, ' $n$ ' is the number of samples of $P$. oceanica collected independently on the sea floor. Each sample comprised ca 8 to 12 scales belonging to the same lepidochronological year. P. oceanica samples collected at the same site are not necessarily of the same age, therefore some younger $P$. oceanica did not yet have very old scales. Nevertheless, the mean number of lepidochronological years (MNLY) was evaluated and $P$. oceanica rhizomes

Table 1. Posidonia oceanica. Metal concentrations ( $\mu \mathrm{g} \mathrm{g}^{-1} \mathrm{dry} w \mathrm{w}$ ) in scales collected in Corsica as a function of lepidochronological years

\begin{tabular}{|ccccccc|}
\hline Year & $\mathrm{n}$ & $\mathrm{Cd}$ & $\mathrm{Cu}$ & $\mathrm{Fe}$ & $\mathrm{Pb}$ & $\mathrm{Zn}$ \\
\hline 1976 & 1 & 1.42 & 9.3 & 948 & 11.9 & 23 \\
1977 & 1 & 0.83 & 6.2 & 460 & 10.0 & 15 \\
1978 & 2 & 0.73 & $14.6 \pm 7.5$ & $828 \pm 370$ & $12.0 \pm 6.9$ & $21 \pm 6$ \\
1979 & 2 & $0.76 \pm 0.04$ & $9.0 \pm 2.6$ & $349 \pm 40$ & $4.4 \pm 1.6$ & $21 \pm 5$ \\
1980 & 2 & $1.07 \pm 0.20$ & $10.9 \pm 5.8$ & $345 \pm 42$ & $4.8 \pm 2.5$ & $15 \pm 1$ \\
1981 & 3 & $1.17 \pm 0.40$ & $8.4 \pm 3.9$ & $431 \pm 153$ & $5.0 \pm 2.4$ & $15 \pm 5$ \\
1982 & 6 & $1.34 \pm 0.12$ & $7.6 \pm 1.4$ & $432 \pm 35$ & $5.9 \pm 0.9$ & $30 \pm 6$ \\
1983 & 8 & $1.35 \pm 0.12$ & $6.9 \pm 0.8$ & $434 \pm 55$ & $5.3 \pm 1.1$ & $17 \pm 2$ \\
1984 & 8 & $1.41 \pm 0.11$ & $6.4 \pm 0.8$ & $334 \pm 32$ & $4.7 \pm 0.7$ & $15 \pm 3$ \\
1985 & 8 & $1.27 \pm 0.23$ & $6.8 \pm 1.3$ & $283 \pm 41$ & $3.5 \pm 0.4$ & $17 \pm 5$ \\
1986 & 8 & $1.28 \pm 0.10$ & $7.2 \pm 1.5$ & $333 \pm 49$ & $6.2 \pm 1.9$ & $19 \pm 4$ \\
1987 & 8 & $1.49 \pm 0.20$ & $7.4 \pm 0.8$ & $350 \pm 37$ & $4.0 \pm 0.9$ & $13 \pm 2$ \\
1988 & 8 & $1.41 \pm 0.22$ & $8.1 \pm 0.9$ & $338 \pm 35$ & $5.7 \pm 0.9$ & $19 \pm 3$ \\
1989 & 8 & $1.15 \pm 0.14$ & $8.8 \pm 0.9$ & $308 \pm 32$ & $5.1 \pm 0.6$ & $17 \pm 2$ \\
1990 & 8 & $1.00 \pm 0.17$ & $9.1 \pm 0.8$ & $228 \pm 12$ & $3.4 \pm 0.6$ & $17 \pm 1$ \\
1991 & 8 & $0.90 \pm 0.17$ & $10.4 \pm 1.9$ & $188 \pm 16$ & $3.0 \pm 0.6$ & $22 \pm 4$ \\
1992 & 8 & $1.05 \pm 0.08$ & $7.6 \pm 0.9$ & $109 \pm 24$ & $1.7 \pm 0.3$ & $27 \pm 9$ \\
& & & & & & \\
\hline
\end{tabular}

Table 2. Posidonia oceanica. Metal concentrations ( $\mu \mathrm{g} \mathrm{g}^{-1} \mathrm{dry}$ wt) in seagrass scales collected at Rochambeau (Villefranche-sur-Mer), France, as a function of lepidochronological years

\begin{tabular}{|ccccccc|}
\hline Year & $\mathrm{n}$ & $\mathrm{Cd}$ & $\mathrm{Cu}$ & $\mathrm{Fe}$ & $\mathrm{Pb}$ & $\mathrm{Zn}$ \\
\hline 1984 & 1 & 1.32 & 40.1 & 2872 & 39.5 & 130 \\
1985 & 2 & $1.36 \pm 0.30$ & $27.8 \pm 4.3$ & $2557 \pm 262$ & $43.4 \pm 6.6$ & $71 \pm 7$ \\
1986 & 2 & $1.17 \pm 0.26$ & $17.3 \pm 1.1$ & $1899 \pm 171$ & $39.7 \pm 2.5$ & $63 \pm 3$ \\
1987 & 2 & $0.99 \pm 0.15$ & $18.8 \pm 2.3$ & $2369 \pm 291$ & $54.7 \pm 25.7$ & $48 \pm 3$ \\
1988 & 2 & $0.89 \pm 0.25$ & $17.2 \pm 1.6$ & $1521 \pm 240$ & $53.4 \pm 21.2$ & $34 \pm 3$ \\
1989 & 2 & $0.39 \pm 0.11$ & $9.4 \pm 1.0$ & $835 \pm 127$ & - & $65 \pm 18$ \\
1990 & 2 & $0.34 \pm 0.12$ & $7.4 \pm 0.1$ & $505 \pm 42$ & 8.9 & $30 \pm 6$ \\
1991 & 2 & $0.65 \pm 0.21$ & $9.2 \pm 0.1$ & $714 \pm 67$ & $14.1 \pm 0.6$ & $32 \pm 1$ \\
1992 & 2 & $0.45 \pm 0.11$ & $8.4 \pm 1.0$ & $426 \pm 12$ & $4.6 \pm 0.1$ & $32 \pm 3$ \\
& & & & & & \\
\hline
\end{tabular}

Two pathways exist for the accumulation of trace metals in the stems and leaves of rooted aquatic plants (Campbell \& Tessier 1989): (1) direct uptake from the water column or (2) uptake from the interstitial water in the sediments, followed by acropetal translocation from the roots to the rhizomes and leaves. This same duality of pathways exists for other solutes (e.g. phosphorus) and both accumulation routes may be operative in the same plant (Denny 1980). In a field situation, it is clearly difficult to distinguish between the 2 possible uptake vectors: the least ambiguous 'integrator' of metal bioavailability in the sediments will be the metal levels in the underground part of the plant, including the roots and rhizomes, and simple relationships between metal concentrations in the plant and total metal concentrations in the sediments were rarely observed, as underlined by Campbell \& Tessier (1989). Nevertheless, for the marine phanerogam eelgrass Zostera marina, Lyngby \& Brix (1982) analyzed heavy metal concentrations in the plant, in the sediments and in the water; they found that concentrations in above- and belowground parts of the eelgrass reflected either the concentrations in the sediments $(\mathrm{Cu}, \mathrm{Pb}$, $\mathrm{Zn})$ or the concentrations in the ambient water (Cd). Faraday \& Churchill (1979) found that cadmium was translocated from the leaves to the root-rhizomes of $Z$. marina, but no translocation in the opposite direction could be detected. Welsh \& Denny (1980) reported a positive correlation be- 
Table 3. Metal concentrations ( $\mathrm{gg} \mathrm{g}^{-1}$ dry wt) in Posidonia oceanica scales collected at La Darse (Villefranche-sur-Mer) as a function of lepidochronological years

\begin{tabular}{|ccccccc|}
\hline Year & $\mathrm{n}$ & $\mathrm{Cd}$ & $\mathrm{Cu}$ & $\mathrm{Fe}$ & $\mathrm{Pb}$ & $\mathrm{Zn}$ \\
\hline 1983 & 1 & 0.94 & 27.1 & 1957 & 26.1 & 147 \\
1984 & 2 & $0.94 \pm 0.44$ & $33.6 \pm 4.0$ & $1247 \pm 153$ & $14.5 \pm 1.9$ & $56 \pm 14$ \\
1985 & 5 & $0.49 \pm 0.08$ & $27.9 \pm 3.3$ & $806 \pm 191$ & $10.4 \pm 2.6$ & $42 \pm 8$ \\
1986 & 5 & $0.43 \pm 0.10$ & $27.7 \pm 5.3$ & $731 \pm 116$ & $8.7 \pm 2.9$ & $42 \pm 9$ \\
1987 & 5 & $0.48 \pm 0.10$ & $31.5 \pm 1.2$ & $920 \pm 256$ & $16.6 \pm 5.2$ & $37 \pm 5$ \\
1988 & 5 & $0.74 \pm 0.01$ & $38.9 \pm 2.4$ & $1143 \pm 439$ & $21.5 \pm 9.9$ & $55 \pm 11$ \\
1989 & 5 & $0.40 \pm 0.13$ & $33.6 \pm 7.8$ & $542 \pm 21$ & $10.4 \pm 0.9$ & $41 \pm 3$ \\
1990 & 5 & $0.34 \pm 0.07$ & $41.1 \pm 9.0$ & $584 \pm 61$ & $8.2 \pm 0.5$ & $42 \pm 10$ \\
1991 & 5 & $0.43 \pm 0.06$ & $39.8 \pm 7.2$ & $536 \pm 12$ & $10.2 \pm 1.0$ & $34 \pm 4$ \\
1.992 & 5 & $0.57 \pm 0.07$ & $46.3 \pm 6.1$ & $115 \pm 21$ & $1.6 \pm 0.3$ & $50 \pm 5$ \\
& & & & & & \\
\hline
\end{tabular}

Table 4. Metal concentrations ( $\mu \mathrm{g} \mathrm{g}^{-1} \mathrm{dry} \mathrm{wt}$ ) in Posidonia oceanica scales collected at Cap Martin as a function of lepidochronological years

\begin{tabular}{ccccccc|}
\hline Year & $\mathrm{n}$ & $\mathrm{Cd}$ & $\mathrm{Cu}$ & $\mathrm{Fe}$ & $\mathrm{Pb}$ & $\mathrm{Zn}$ \\
\hline 1986 & 1 & - & 35.8 & 1774 & - & 133 \\
1987 & 2 & $1.42 \pm 0.05$ & $16.1 \pm 2.7$ & $1012 \pm 197$ & $22.1 \pm 1.1$ & $51 \pm 3$ \\
1988 & 5 & $0.84 \pm 0.14$ & $12.5 \pm 0.4$ & $972 \pm 150$ & $8.8 \pm 0.7$ & $59 \pm 10$ \\
1989 & 6 & $0.90 \pm 0.31$ & $1.6 .3 \pm 3.5$ & $782 \pm 88$ & $12.4 \pm 2.0$ & $59 \pm 10$ \\
1990 & 9 & $0.57 \pm 0.12$ & $12.4 \pm 0.7$ & $879 \pm 96$ & $11.0 \pm 1.5$ & $49 \pm 6$ \\
1991 & 9 & $0.64 \pm 0.08$ & $11.1 \pm 0.8$ & $723 \pm 51$ & $6.0 \pm 0.6$ & $41 \pm 5$ \\
1992 & 9 & $0.61 \pm 0.07$ & $11.9 \pm 1.3$ & $472 \pm 57$ & $2.5 \pm 0.5$ & $35 \pm 5$ \\
& & & &
\end{tabular}

lepidochronological years 1989 to 1980 ) in rhizomes and scales while $\mathrm{N}$ and $\mathrm{P}$ content decreased sharply in the rhizomes but remained constant $(\mathrm{N})$ or increased $(\mathrm{P})$ in the scales. Contrary to rhizomes, scales are without doubt clead organs, with no or low exchanges with the living part of the plant, so that metals included and stored during the leaf life could not then be removed and leachage of metals from scales could not occur. In the scales, strong retention of metals may be due to intracellular binding to biochemical constituents such as proteins, amino acids, carbohydrates or polyphenols. Cariello \& Zanetti (1979) reported that the major phenolic compound in $P$. oceanica was chicoric acid; nevertheless, in sheaths (scales) its concentration was found to be very low, which minimises its role in metal storage. Polyphosphate bodies, refractive intracellular inclusions composed mainly of condensed polyphosphates, lipids and proteins, may also provide a storage site for metals. They have been found in microalgae exposed to $\mathrm{Cd}, \mathrm{Co}, \mathrm{Cu}, \mathrm{Hg}, \mathrm{Ni}, \mathrm{Pb}$ and $\mathrm{Zn}$ (Jensen et al. 1982) and in the marine alga Macrocystis pyrifera (Walsh \& Hunter 1992) treated with $\mathrm{Cd}$.

tween copper and lead concentrations in Potamogeton crispus and $P$. perfoliatus (species belonging to the Family of Potamogetonaceae, as do Zostera marina and Posidonia oceanica) and in sediment.

In the case of Posidonia oceanica, Maserti et al. (1991) showed a mercury content of $0.27 \pm 0.05 \mu \mathrm{g} \mathrm{Hg}$ $\mathrm{g}^{-1}$ dry wt in the scales of samples collected in front of a chlor-alkali plant near Livorno (Tyrrhenian Sea) while scales sampled in a nonpolluted area contained $0.02 \pm 0.01 \mu \mathrm{g} \mathrm{Hg} \mathrm{g}^{-1} \mathrm{dry}$ wt. These contents were correlated with mercury levels in the sediments but not with dissolved mercury levels which were the same in the 2 studied areas. The authors concluded that the uptake of mercury in $P$. oceanica occurred mainly through the root apparatus, but they did not exclude that the metal can also be taken up from the water at a lower rate by the leaves.

Apart from environmental conditions (trace metal concentrations in water or in sediments), the physiological state of the seagrass is important when considering heavy metal uptake. The specific tissues studied in this paper are the scales of Posidonia oceanica (sheathing bases attached to the rhizomes). Recently, Pergent et al. (1994) studied the decay kinetics of carbon, nitrogen and phosphorus in scales and rhizomes collected in the Mediterranean, by means of lepidochronological data. There was a slight $\mathrm{C}$ loss with time (ca 10 yr from the
Trace metal contents found in the scales of Posidonia oceanica will be discussed as a function of lepidochronological years and of sampling sites taking into account the accumulation pathways of the abovementioned metals.

\section{Cadmium}

The case of $\mathrm{Cd}$ (Fig. 2a) is interesting since scales collected in the cleanest area showed a higher content of this metal $\left(1.22 \pm 0.50 \mu \mathrm{g} \mathrm{Cd} \mathrm{g}^{-1}, \mathrm{n}=96\right.$ samples, all lepidochronological years put together) than scales from other areas $\left(0.72 \pm 0.56 \mu \mathrm{g} \mathrm{Cd} \mathrm{g}^{-1}, \mathrm{n}=88\right)$. Differences between the means were significant ( $t$-test, significant at $p<0.001$ ). Cadmium concentrations in Posidonia oceanica scales from Corsica fluctuated as a function of lepidochronological years whereas a slight decrease with time was generally observed in samples from the Côte d'Azur.

Carlotti et al. (1992) reported cadmium concentrations in Posidonia oceanica scales collected in Corsica (in the protected area of Scandola, northwest Corsica;

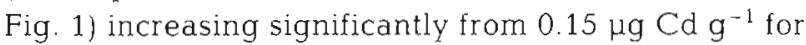
lepidochronological years 1962 to 1966 to $1.87 \mu \mathrm{g} \mathrm{Cd}$ $\mathrm{g}^{-1}$ for $1986_{i}$ the authors hypothesized that this phenomenon may be due to a slow increase of cadmium 

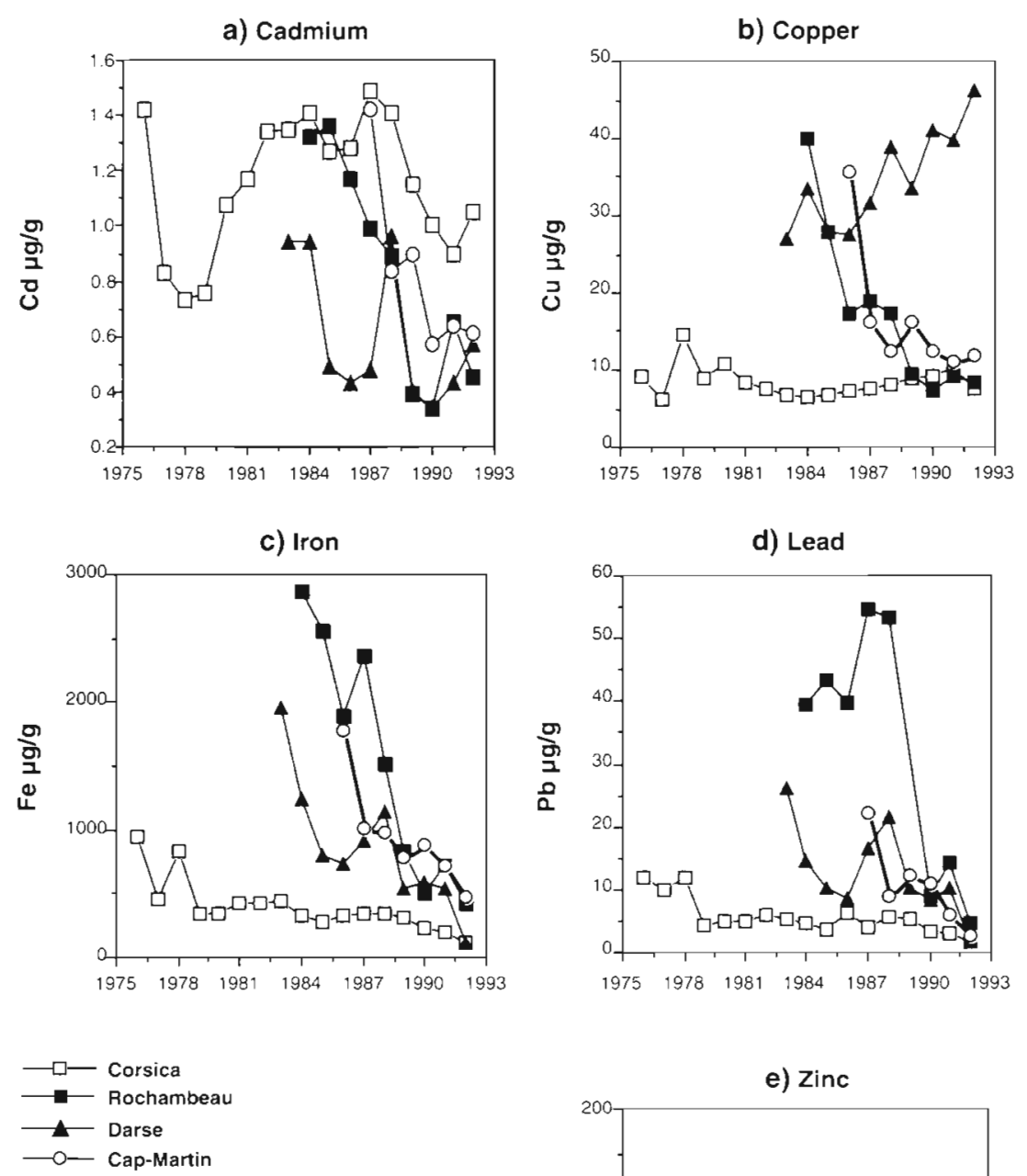

Fig. 2. Posidonia oceanica. Mean metal concentrations in seagrass scales as a function of lepidochronological years: (a) cadmium, (b) copper, (c) iron, (d) lead, (e) zinc. Standard deviations of means are given in Tables 1 to 4 for Corsica, Rochambeau, La Darse, and Cap Martin, respectively

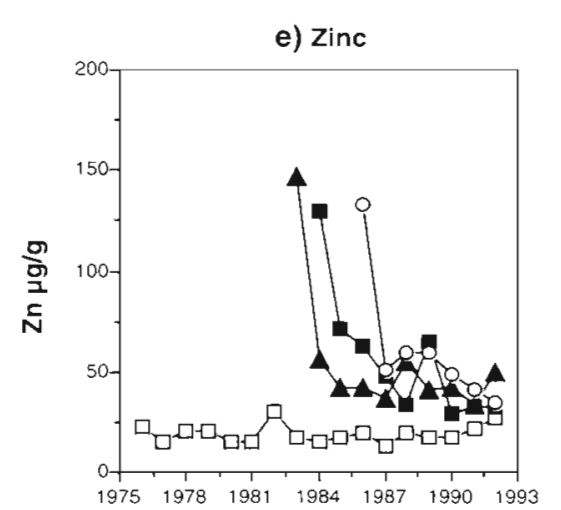

the tissues of Zostera marina, higher $\mathrm{Cd}$ values found in the scales from Corsica may be due to a natural phenomenon such as the upwelling of deep waters rich in cadmium. Such an explanation was given by Pergent-Martini (1992) who found elevated cadmium concentrations: mean values ranging from $2.50(1970)$ to $1.90 \mu \mathrm{g} \mathrm{Cd} \mathrm{g}{ }^{-1}$ (1990) in Posidonia oceanica scales sampled in the Bay of Calvi (northwest Corsica; Fig. 1). More generally, Fowler (1990) reported surface enrichment in waters (up to $13.8 \mathrm{ng} \mathrm{Cd} \mathrm{l}^{-1}$ ) from some areas of the Mediterranean; however, it was not evident whether this enrichment was due to natural or anthropogenic sources.

\section{Copper}

Copper concentrations (Fig. 2b) in Posidonia oceanica scales from Corsica showed little variation as a function of lepidochronological years. These values are in good agreement with those reported by Pergent-Martini (1992): a variation range of 7 to $15 \mu \mathrm{g} \mathrm{Cu} \mathrm{g}^{-1}$ in scales dated from 1975 to 1991 (P. oceanica collected from Calvi). A significant decrease as a function of lepidochronological years was observed in copper concentrations in P. oceanica scales from Rochambeau and from Cap Martin, whereas an increase in concentrations was observed in samples from the harbour of La Darse. Copper concentrations in $P$. oceanica scales

concentrations in the waters of this area as a function of time. On the other hand, P. oceanica scales sampled in a bay ('Anse de la Beaumaderie') subjected to considerable industrial pollution from the Gulf of Fos, the river Rhône and the city of Marseilles, France, showed a mean value of $3.5 \mu \mathrm{g} \mathrm{Cd} \mathrm{g}^{-1}$, not varying with lepidochronological years (Carlotti et al. 1992). This value is higher than our mean value for Corsica $(1.22 \mu \mathrm{g} \mathrm{Cd}$ $\mathrm{g}^{-1}$ ) and much higher than what we reported for the sampling stations on the Côte d'Azur.

If we assume that $\mathrm{Cd}$ in seagrass tissues reflects $\mathrm{Cd}$ in the water, as observed by Lyngby \& Brix (1982) for dated in the lepidochronological years 1983 to 1985 were relatively high and not significantly different at the 2 sampling stations at Villefranche-sur-Mer, i.e. Rochambeau and La Darse. These values could reflect the copper concentrations found in sediments of the studied area, at the period when scales were formed. High copper concentrations were reported for superficial sediments collected in 1980 from the same sampling stations (>40 $\mathrm{gg} \mathrm{Cu} \mathrm{g}{ }^{-1}$ dry sediment; Rapin \& Fernex 1981). From the lepidochronological year 1985, copper concentrations in scales collected from La Darse harbour began to increase and were higher than 
in scales from Rochambeau. Means, calculated for all lepidochronological years, reached $34.3 \pm 11.1 \mu \mathrm{g} \mathrm{Cu}$ $g^{-1}, \mathrm{n}=37$ for La Darse, which is significantly higher ( $t$ test, significant at $p<0.001$ ) than the mean of $15.6 \pm 9.3$ $\mu \mathrm{g} \mathrm{Cu} \mathrm{g}{ }^{-1}, \mathrm{n}=17$ for Rochambeau. These high Cu concentrations in scales from La Darse may be due to the influence of antifouling paints, from boat hulls or used in the nearby shipyard. Claisse \& Alzieu (1993) reported an increase of copper content in oysters harvested in a zone located in the vicinity of marinas and mooring areas. This increase, recorded since 1982, may be attributable, according to the authors, to the growing use of copper paints subsequent to the antifouling paint regulations adopted in France in 1982. Stephenson \& Leonard (1994) found an increase of copper from 1977 to 1990 in the coastal marine waters of California, USA, which appeared to be related to increased traffic and use of new, copolymer antifouling paints.

\section{Iron}

Iron concentrations (Fig. 2c) in Posidonia oceanica scales always showed higher values in samples from the Côte d'Azur than in those from Corsica. Moreover, they significantly decreased as a function of lepidochronological years. For instance, concentrations ranged from 2557 (1985) to $426 \mu \mathrm{g} \mathrm{Fe} \mathrm{g}^{-1}$ (1992) in Rochambeau samples and from 828 (1978) to $109 \mu \mathrm{g} \mathrm{Fe}$ $\mathrm{g}^{-1}$ (1992) in Corsica samples. The same decrease was observed by Pergent-Martini (1992) on P. oceanica scales collected from Calvi: the values ranged from. 1200 (1.975) to ca $200 \mu \mathrm{g} \mathrm{Fe} \mathrm{g}^{-1}$ (1991). This author stated that the decrease does not necessarily reflect a decrease in pollution but may result from temporary physicochemical characteristics of the environment or from biochemical modifications linked to the biology of the species. More metal binding sites (e.g. - $\mathrm{OH},-\mathrm{SH}$ ) may be liberated on perennial cellulose cell walls and become available for iron uptake as scales are aging. Another hypothesis to explain the high iron concentrations found in the scales of $P$. oceanica could be that ferrous iron diffusing from reducing zones in sediments (as reported by Fowler 1982) is oxidized at the scale surface and remains adsorbed. This would result in higher concentrations in basal scales, which are the oldest and the nearest to the sediments.

\section{Lead}

Lead concentrations (Fig. 2d) in Posidonia oceanica scales from Corsica varied little as a function of lepidochronological years from 1979. At the 3 other sampling stations (Côte d'Azur), concentrations were high, particularly at La Darse (26.1 $\mathrm{g} \mathrm{Pb} \mathrm{g}^{-1}$, lepidochronological year 1983) and Rochambeau $\left(39.5 \mu \mathrm{g} \mathrm{Pb} \mathrm{g}^{-1}, 1984\right)$, and highly variable with time. Lead concentrations in superficial sediments from the sampling area at Villefranche-sur-Mer (Rochambeau and La Darse) were reported to be high $\left(>200 \mu \mathrm{g} \mathrm{g}^{-1}\right.$; Rapin \& Fernex 1981). Adsorption of lead released from sediments (Fowler 1982) onto the cellulose cell wall of $P$. oceanica scales may have occurred. Uptake experiments carried out with ${ }^{210} \mathrm{~Pb}$ and marine algae demonstrated that lead is easily bound to algal surfaces (Fisher et al. 1983). However, a significant decrease as a function of lepidochronological years was observed, lead contents in scales of $P$. oceanica from the Côte d'Azur dated in 1992 were nearly the same as those found for Corsica samples. High lead concentrations were recorded in phytoplankton and zooplankton organisms collected along the coastline between Nice and Villefranchesur-Mer (Roméo et al. 1985) whereas the same organisms presented much lower lead concentrations when sampled in the open sea in a transect between Nice and Corsica. Roméo et al. (1985) suggested that plankton organisms were polluted by fallout from atmospheric lead. Lead, in tetra-ethyl form, is emitted into the atmosphere by car exhausts. Fowler (1990) emphasized that the major source of $\mathrm{Pb}$ to the coastal zone is atmospheric input. Lead enters the NW Mediterranean Sea through both rainfall and dry deposition (Migon et al. 1991). P. oceanica scales may, therefore, memorize the progressive decrease in lead concentrations in sea water recorded between 1986 and 1992 in our sampling area and attributed to the increasing use of unleaded gasoline (Migon et al. 1993).

\section{Zinc}

Zinc concentrations (Fig. 2e) in Posidonia oceanica scales from Corsica were found to be low compared to those from the Cote d'Azur. They showed a great stability as a function of lepidochronological years, whereas a decrease was observed in samples from the 3 sampling stations on the Cote d'Azur Generally, the variations of zinc concentrations in $P$. oceanica scales paralleled those of iron and lead. Diffusion from the nearby sediments and coprecipitation with iron may also take place in the oldest scales.

\section{CONCLUSIONS}

Among the results reported here (5 metals analysed on ca 180 samples of scales), without taking into account the concentrations of copper in scales from the 
harbour at La Darse (Villefranche-sur-Mer), there was a general tendency for metal concentrations in Posidonia oceanica scales collected on the Côte d'Azur to decrease as a function of lepidochronological years, the oldest scales having the highest metal concentrations (analysis of lepidochronological years from 1982 to 1992). Scales of $P$. oceanica collected in Corsica (analysis of lepidochronological years from 1972 to 1992), a very clean area from the Mediterranean, showed lower copper, iron, lead and zinc concentrations than those from the Cote d'Azur with a decrease as a function of time for iron and lead concentrations. Higher cadmium concentrations were recorded in $P$. oceanica scales from Corsica; the reasons (which may be natural) for these high values are still unknown and deserve further attention. In the channel leading to the pleasure-boat harbour at Villefranche-sur-Mer, high copper concentrations were determined in $P$. oceanica scales; these concentrations increased as a function of lepidochronological years.

The analysis of heavy metals in Posidonia oceanica scales may provide a suitable retrodating biomonitor in the case of cadmium, copper and lead. Iron and zinc concentrations may be less suitable as biomonitors since these metals may diffuse from nearby sediments.

Posidonia oceanica, widely spread over the western and eastern Mediterranean, has been reported to be a good bioindicator species. Nevertheless, this species is sensitive to acute levels of pollution, being absent near sewage outfalls (Pérès \& Picard 1975). However, the seagrass can also be considered as a good biomonitor as defined by Rainbow \& Phillips (1993), the term biomonitor denoting an aquatic species which accumulates trace metals in its tissues and may therefore be analysed to monitor the bioavailability of such contaminants in estuarine or coastal ecosystems. Biomonitors must also provide time-integrated measures of the bioavailable metals. In this study, the pooling together of scales of $P$. oceanica belonging to the same lepidochronological year allowed us to smooth out possible seasonal variations, since Panayotidis et al. (1990) observed an annual cycle of bioaccumulation of $\mathrm{Cu}, \mathrm{Cd}$ and $\mathrm{Cr}$ in the scales of $\mathrm{P}$. oceanica. Fowler (1986) noted no significant differences in metal concentrations in similar organisms from the Mediterranean between 1974-75 and 1977 and emphasized that the 2 yr interval is short and may not be sufficient to register changes brought about by anthropogenic sources. The study of trace metal concentrations in dated scales of $P$. oceanica (which may be 10 or 20 yr old) could allow a global monitoring programme in Mediterranean coastal areas with good feasibility and would not be hampered in terms of costs.
Acknowledgements. This work was done in the framework of a research programme funded by Conseil Régional de la Région Provence-Alpes-Còte d'Azur (file number 92/0031200 CR PACA/Puiseux-Dao). We are grateful to Prof. Puiseux-Dao and Dr C. Pergent-Martini for fruitful discussion.

\section{LITERATURE CITED}

Augier, H., Gilles, G., Ramonda, G. (1977). Utilisation de la phanérogame marine Posidonia oceanica (L.) Delile pour mesurer le degré de contamination mercurielle des eaux littorales méditerranéennes. C.r. Acad. Sci., Paris 285. $1557-1560$

Boudouresque, C. F., Crouzet, A., Pergent, G. (1983). Un nouvel outil au service de l'étude des herbiers à Posidonia oceanica: la lépidochronologie. Rapp. P.v. Réun Comm. int. Explor, sci. Médit. 28: 111-112

Calmet, D., Boudouresque, C. F., Meinesz, A. (1988). Memorization of nuclear atmospheric tests by rhizomes and scales of the Mediterranean seagrass Posidonia oceanica (Linnaeus) Delile. Aquat. Bot. 30: 279-294

Campbell, P. G C., Tessier, A. (1989). Geochemistry and bioavailability of trace metals in sediments. In: Boudou, A., Ribeyre, F. (eds.) Aquatic ecotoxicology: fundamental concepts and methodologies, Vol. 12. CRC Press, Boca Raton, p. 125-148

Cariello, L., Zanetti, L. (1979). Distribution of chicoric acid during leaf development of Posidonia oceanica. Botanica mar. 22: $359-360$

Carlotti, P., Boudouresque, C. F., Calmet, D. (1992). Mémorisation du cadmium et de radioéléments par les rhizomes et Jes écailles de Posidonia oceanica (Potamogetonaceae). Trav. sci. Parc nat. rég. Rés. nat. Corse, France 36: 1-34

Chabert, D., Vicente, N., Huang, W. (1983). La pollution par les métaux lourds dans les rades du Parc national de PortCros. II. Contrôle pluriannuel. Trav. sci. Parc nat. PortCros 10: 51-67

Claisse, D., Alzieu, Cl. (1993). Copper contamination as a result of antifouling paint regulations? Mar. Pollut. Bull. 26(7): $395-397$

Denny, P. (1980). Solute movement in submerged angiosperms. Biol. Rev. 56: 65-92

Faraday, W. E., Churchill, A. C. (1979). Uptake of cadmium by the eelgrass Zostera marina. Mar. Biol. 53: 293-298

Fisher, N. S., Burns, K. A., Cherry, R. D., Heyraud, M. (1983). Accumulation of ${ }^{241} \mathrm{Am},{ }^{210} \mathrm{Po}$ and ${ }^{210} \mathrm{~Pb}$ in two marine algae. Mar. Ecol. Prog. Ser. 11. 233-237

Fowler, S. W. (1982). Biological transfer and transport processes. In: Kullenberg, G. (ed.) Pollutant transfer and transport in the sea, Vol. 2. CRC Press, Boca Raton, p. $2-65$

Fowler, S. W. (1986). Trace metal monitoring of pelagic organisms from the open Mediterranean sea. Environ. Monitoring Assessment 7: 59-78

Fowler, S. W. (1990). Critical review of selected heavy meta] and chlorinated hydrocarbon concentrations in the marine environment. Mar. environ. Res. 29: 1-64

Gnassia-Barelli, M., Roméo, M., Delépine, R., Puel, D. (1991). Trace metal concentrations in benthic algae from French Mediterranean and Atlantic coasts. Oebalia 17(1) (suppl. 91): $245-251$

Jensen, T. E., Baxter, M., Rachlin, J. W., Jani, V (1982). Uptake of heavy metals by Plectonema boryanum (Cyanophyceae) into cellular components, especially polyphosphate boldies: an X-ray energy dispersive study. Environ. Pollut. Ser. A 27: 119-127 
Lyngby, J. E., Brix, H. (1982). Seasonal and environmental variation in cadmium, copper, lead and zinc concentrations in eelgrass (Zostera marina L.) in the Limfjord, Denmark. Aquat. Bot. 14: 59-74

Malea, P., Haritonidis, S. (1989). Uptake of $\mathrm{Cu}_{1} \mathrm{Cd}, \mathrm{Zn}$ and $\mathrm{Pb}$ in Posidonia oceanica (Linnaeus) from Antikyra Gulf, Greece: preliminary note. Mar. environ. Res. 28: 495-498

Maserti, B. E., Ferrara, R., Morelli, M. (1991). Posidonia oceanica: uptake and mobilization of mercury in the Mediterranean Basin. In: Gabrielides, G. P. (ed.) MAP Technical Reports Series 59. UNEP, Athens, p. 243-249

Maserti, B. E., Ferrara, R., Patterno, P. (1988). Posidonia as an indicator of mercury contamination. Mar. Pollut. Bull. 19(8). 381-382

Meinesz, A., Lefevre, J. R., Astier, J. M. (1990). Impact of coastal development on the infralittoral zone along the southeastern Mediterranean shore of continental France. Mar. Pollut. Bull. 23: 343-345

Migon, C., Alleman, L., Leblond, N., Nicolas, E. (1993). Evolution of atmospheric lead over the north-western Mediterranean between 1983 and 1992. Atmos. Environ. 27 A: $2161-2167$

Migon, C., Morelli, J., Nicolas, E., Copin-Montégut, G. (1991). Evaluation of total atmospheric deposition of $\mathrm{Pb}, \mathrm{Cd}, \mathrm{Cu}$ and $\mathrm{Zn}$ to the Ligurian Sea. Sci. Total Environ. 105: $135-148$

Panayotidis, P., Makris, P., Catsiki, V. A. (1990). Cycle de bioaccumulation du $\mathrm{Cu}, \mathrm{Cd}$ et $\mathrm{Cr}$ dans les écailles de Posidonia oceanica. Rapp. Comm. int. Mer Médit. 32: 1

Pérès, J. M., Picard, J. (1975). Causes de la raréfaction et de la disparition des herbiers de Posidonia oceanica sur les côtes françaises de la Méditerranée. Aquat. Bot. 1: $133-139$

Pergent, G. (1987). Recherches lépidochronologiques chez Posidonia oceanica (Potamogetonaceae). Fluctuations des paramètres anatomiques et morphologiques des écailles des rhizomes. Thèse de doctorat, Université d'AixMarseille II

This article was submitted to the editor
Pergent, G., Boudouresque, C. F., Crouzet, A. (1983). Variations cycliques dans les écailles des rhizomes orthotropes de Posidonia oceanica. Trav. sci. Parc nat. Port-Cros 9: $107-148$

Pergent, C., Boudouresque, C. F., Crouzet, A., Meinesz, A. (1989). Cyclic changes along Posidonia oceanica rhizomes (lepidochronology): present state and perspectives. P.S.Z.N. I: Mar. Ecol. 10: 221-230

Pergent, G., Romero, J., Pergent-Martini, C., Matteo, M.-A., Boudouresque, C.-F. (1994). Primary production, stocks and fluxes in the Mediterranean seagrass Posidonia oceanica. Mar. Ecol. Prog. Ser. 106: 139-146

Pergent-Martini, C. (1992). Contribution à l'étude des stocks et des flux d'éléments dans l'écosystème à Posidonia oceanica. D.E.S.S. 'Ecosystèmes méditerranéens'. Université de Corse, Corte

Rainbow, P. S., Phillips, D. J. H. (1993). Cosmopolitan biomonitors of trace metals. Mar. Pollut. Bull. 26: 593-601

Rapin, F., Fernex, F. (1981). Teneurs en métaux lourds dans les sédiments de Nice et de Villefranche-sur-Mer. Rev. Int. Océanogr. Méd. 63/64: 85-96

Roméo, M., Gnassia-Barelli, M., Carré, C. (1992). Importance of gelatinous plankton organisms in storage and transfer of trace metals in the northwestern Mediterranean. Mar. Ecol. Prog. Ser 82: $267-274$

Roméo, M., Gnassia-Barelli, M., Nicolas, E. (1985). Concentrations en plomb du plancton de la mer Ligure (Méditerranée Nord-Occidentale). Chemosphere 14(9): 1423-1431

Stephenson, M. D., Leonard, G. H. (1994). Evidence for the decline of silver and lead and the increase of copper from 1977 to 1990 in the coastal marine waters of California. Mar. Pollut. Bull 28: 148-153

Walsh, R. S., Hunter, K. A. (1992). Influence of phosphorus storage on the uptake of cadmium by the marine alga Macrocystis pyrifera. Limnol. Oceanogr. 37: 1361-12369

Welsh, R. P. H., Denny, P. (1980). The uptake of lead and copper by submerged macrophytes in two English lakes. J. Ecol. 68: 443-4.55

Manuscript first received: June 20, 1994

Revised version accepted: January 4, 1995 